\title{
触 New Disease Reports \\ First report of Puccinia dracunculina on Artemisia dracunculus in Turkey
}

\author{
H. Kavak ${ }^{1 *}$ and A. Bilgili ${ }^{2}$ \\ ${ }^{1}$ Dicle University, Agricultural Faculty, Plant Protection Department, 21280 Diyarbakır, Turkey; ${ }^{2}$ GAPTAEM, Plant Health \\ Department, Şanlıurfa, Turkey
}

*E-mail: hamit.kavak@dicle.edu.tr

Received: 01 Apr 2015. Published: 14 Jun 2015.

Artemisia dracunculus var. sativa (tarragon) is a medicinal and spice plant,
grown commonly in home gardens, in southern and southeastern districts of
Turkey. It has also been cultivated organically in fields of the Şanliurfa
region in southeastern Anatolia for over a decade. During surveys
performed in early summer 2014, a severe rust disease was observed on
organically cultivated tarragon plants in this location. The severity of the
disease attack appeared to increase during the summer season. Many
leaves, covered with dense uredinial pustules (Fig. 1), had died before
flowering.

Uredinia were light brown, globose to irregular, 70-250 $\mu \mathrm{m}$ across, mostly colonising the lower surfaces of leaves with some on the upper surfaces and on the stems. The urediniospores were nearly colourless, had a wall of even thickness and varied in shape to include spherical, ellipsoidal, and pyriform and other irregular forms, 13-22 x 26-38 $\mu$ m (Fig. 2). Some telia, dark brown and 100-300 $\mu \mathrm{m}$ across, occurred on the lower surface of leaves, starting to appear at the end of summer, increasing in autumn (Fig. 3). The teliospores were brown, typically two celled, $21-25 \times 40-55 \mu \mathrm{m}$, with a wall of uneven thickness. Many of the teliospores had characteristic, colourless pedicels that varied in length from 42 to $78 \mu \mathrm{m}$ (Fig. 4). Based on these properties, the rust pathogen was identified as Puccinia dracunculina Fahrend. (Fahrendorff, 1941). The uredinial stage of this rust pathogen was the dominant and active form during the summer season while the telial stage was active in autumn or mid-autumn, similar to the results of Cohen et al. (2013). Although this species is autoecious, basidiospores were not observed.

Pathogenicity tests were performed on one-month-old healthy $A$. dracunculus var. sativa plants grown from rooted cuttings in pots. Using a fine brush, urediniospores were brushed from pustules onto fresh, naturally infected leaves of field tarragon plants held in a petri dish. A suspension of urediniospores was prepared in sterile, distilled water containing one small drop of Tween 20 per $100 \mathrm{ml}$ (Kavak, 2003) and adjusted to $1 \times 10^{4}$ spores per $\mathrm{ml}$. Nine plants were sprayed with the urediniospore suspension and three plants were sprayed with sterilised distilled water as controls. All plants were enclosed in a plastic bag for $48 \mathrm{~h}$ after spraying and kept at $20^{\circ} \mathrm{C}$ in a greenhouse. First symptoms, similar to those on naturally infected plants, occurred two weeks after inoculation on the plants inoculated with the spores but the controls remained symptomless. Urediniospores were later re-isolated from inoculated plants, but not in controls. This rust disease appears to be a major problem on tarragon in Turkey, particularly under organic cultivation in the Şanlıurfa district. According to research, this rust species infects only tarragon and is known throughout the world where this plant is cultivated (Gamliel \& Yarden, 1998). However, to our knowledge this is the first report of P. dracunculina on A. dracunculus in Turkey.

\section{References}

Cohen R, Anikster Y, Vintal J, Manisterski J, Shtienberg D, 2013.

Overwintering and epidemiology of Puccinia dracunculina, the causal agent of rust in open tarragon fields. Plant Pathology 62, 41-48.

http://dx.doi.org/10.1111/j.1365-3059.2012.02630.x

Fahrendorff VE, 1941. Über die Brachypuccinien der Artemisia-arten. Annales Mycologici 39, 158-213.

Gamliel A, Yarden O, 1998. Diversification of diseases affecting herb crops in Israel accompanies the increase in herb crop production. Phytoparasitica 26, 53-58.

Kavak H, 2003. First record of leaf scald caused by Rhynchosporium secalis in natural population of Hordeum vulgare subsp. spontaneum in Turkey. Plant Pathology 52, 805.

http://dx.doi.org/10.1111/j.1365-3059.2003.00914.x

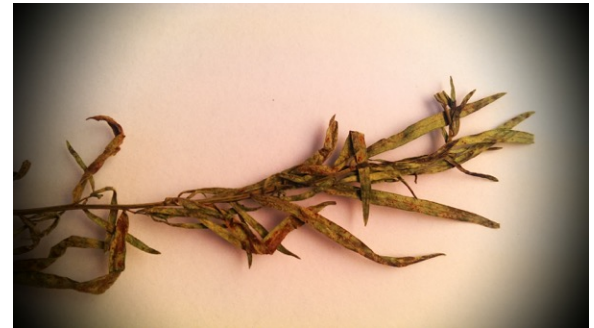

Figure 1

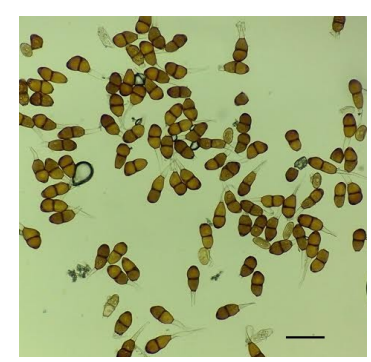

Figure 2
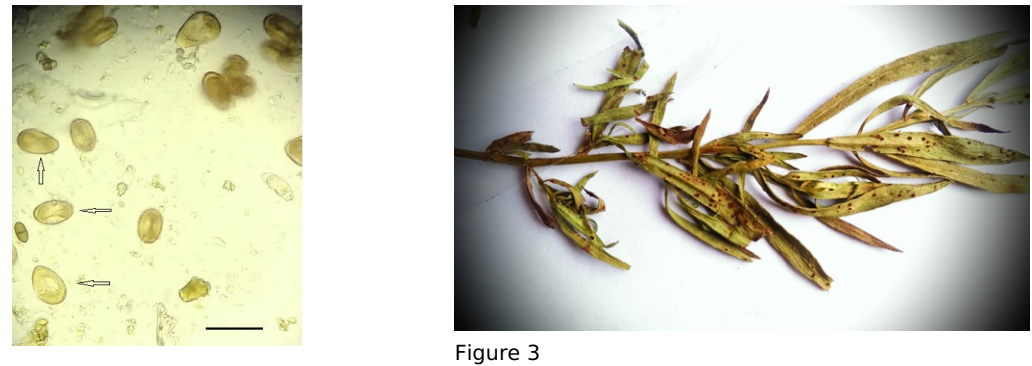

Figure 3

Figure 4

To cite this report: Kavak H, Bilgili A, 2015. First report of Puccinia dracunculina on Artemisia dracunculus in Turkey. New Disease Reports 31, 28. http://dx.doi.org/10.5197/j.2044-0588.2015.031.028 